UDC 336.71

JEL: E58, G21, G28, L16

\author{
Ana Guruli \\ Department of Finances and Bank \\ Technologies, \\ Georgian Technical University \\ Tbilisi, Georgia \\ E-mail: Ana.gurulii@gmail.com \\ orcid.org/0000-0003-0585-1237
}

Received: December 24, 2020

Accepted: February 26， 2021

DOI:10.31520/2616-7107/2021.5.1-3

(C) Economics. Ecology. Socium, 2021 CC BY-NC 4.0 license

\section{THE IMPACT OF THE BANKING SYSTEM CONCENTRATION LEVEL AND THE PANDEMIC ON THE GEORGIAN BANKING SECTOR}

Introduction. The importance of the banking sector is vital for the economic development of any country, since it is the main structural unit of monetary use, which plays the greatest role in the development of the state. As in all markets, we are faced with competition in the banking market, which is characterized by certain specifics, since the main product is money that cannot be replaced by other goods, and the main purpose of competition is to gain an advantage among agents operating in the same market, which is reflected in the final profit. The more the banking market develops and the more diversified the services offered to clients, the more the role of competition in the banking sector increases. The spread of the pandemic not only impeded the development of healthy competition, but also called into question the normal functioning and development of the banking sector.

Aim and tasks. The aim of the study is to determine the level of competition in the Georgian banking sector by the method of identifying total assets and net loans, which aims to identify the causes of the market concentration level and find solutions, as well as to determine and assess the shock effects of the pandemic, because The pandemic period has become an even bigger challenge for the Georgian banking sector, where most of the market players occupy a small volume of the market, the National Bank of Georgia is actively trying to keep up with the challenges, and in order to mitigate the negative impact caused by the pandemic

Results. The results of the study showed the monopoly functioning of the market, which is an obstacle to the development of a competitive market, resulting in unhealthy functioning of the market and the development of a flexible banking system, which ultimately negatively affects the stability of the country's economic development. As for the post-pandemic situation, it has been dealt with quite positively in Georgia, with the management of loan and deposit portfolios successfully managed through a temporary supervisory plan developed by the government, which has not been followed by outflow of funds from banks and loan portfolio mismanagement.

Conclusions. In conclusion, it should be noted that in a highly concentrated market, small banks should be promoted with various legislative benefits, which will lead to competition, it is possible to impose a so-called "Capital tax", which implies high demands on capital, it will allow small banks to develop in a healthy competitive environment. Despite the fact that no bank was disrupted during the virus shock in Georgia, the financial result was so unfavorable, it was damaged, the main reason for which was the provision of possible losses on loans, which amounted to a total of 1.22 billion GEL, the National Bank of Georgia is actively trying to keep up with the challenges.

Keywords: market concentration, pandemic impact, Herfindahl-Hirschman Index, grace period. 
УДК 336.71

JEL: E58, G21, G28, L16
Отримано: 24 грудня, 2020

Прийнято: 26 лютого, 2021

DOI:10.31520/2616-7107/2021.5.1-3

(C) Економіка. Екологія. Соціум, 2021 CC BY-NC 4.0 ліцензія

\section{ВПЛИВ РІВНЯ КОНЦЕНТРАЦІЇ БАНКІВСЬКОЇ СИСТЕМИ ТА ПАНДЕМІЇ НА БАНКІВСЬКИЙ СЕКТОР ГРУЗІї}

Вступ. Важливість банківського сектору життєво необхідна для економічного розвитку будь-якої країни, тому що це основна структурна одиниця грошового обіходу, що відіграє найбільшу роль у розвитку держави. Як і на всіх ринках, ми стикаємося з конкуренцією на банківському ринку, яка характеризується певною специфікою, оскільки основним товаром є гроші, які не можуть бути замінені іншими товарами, а основна мета конкуренції повязана із отриманням переваги серед агентів, які діють на одному ринку, що відображається на кінцевому прибутку. Чим більше розвивається банківський ринок і чим різноманітніші послуги пропонуються клієнтам, тим більше посилюється роль конкуренції в банківському секторі. Поширення пандемії не лише завадило розвитку здорової конкуренції, але й поставив під сумнів нормальне функціонування та розвиток банківського сектору.

Мета і завдання. Метою дослідження є визначення рівня конкуренції в банківському секторі Грузії, методом визначення сукупних активів та чистих позик. Завданням яких $\epsilon$ виявлення основних причин рівня концентрації на ринку та пошук рішень. А також виявлення та оцінка наслідків «шоку», спричиненого пандемією.

Результати. Результати дослідження показали монопольне функціонування ринку, що $є$ перешкодою для розвитку конкурентного ринку, у результаті якого відбувається нездорове функціонування ринку та перешкоджання гнучкому банківському розвитку, що в кінцевому рахунку негативно впливає на стабільність економічного розвитку країни. Що стосується постпандемічної ситуації, то в Грузії боротьба з нею досить позитивно було вирішено. Завдяки тимчасовому плану нагляду, розробленому урядом, було успішно керовано кредитним та депозитним портфелями, що не супроводжувалося відтоком коштів з банків та несправністю управлінням кредитними портфелями.

Висновки. На закінчення треба відмітити, що на висококонцентрованому ринку обов'язково повинно відбутися підтримання малих банків за різними законодавчими вигодами, що призведе до поліпшення конкуренції. Можливо, щоб на провідні банки наклали "Податок на капітал", що передбачає пред'явлення високих вимог до капіталу. Це дозволить малим банкам розвинутись в здоровій конкуренції. Недівлячись на пандемію робота жодного банку не затримувалася, фінансовий результат все ще був несприятливим,основною причиною якого стало надання можливих збитків за позиками, що загалом склало 1,22 мільярда ларі. Незважаючи на це, Національний банк Грузії активно намагається не відставати від викликів і розроблятиме різні плани з метою пом'якшення негативного впливу пандемії та заохочення економіки країни.

Ключові слова: концентрація ринку, вплив пандемії, індекс Герфінд-альгіршман, пільговий період. 
Introduction. In a market economy, when the market is saturated with free-user interactions, banking competition is paramount, as banks no longer have the role of merely accepting deposits, lending or exchanging money. While these functions of banks still exist, modern banks are now focusing more on providing a more convenient payment regime and delivering money that meets the needs of the commercial sector. Precise information on the establishment of the first bank and the development of the system has not been preserved, although there is speculation that the need for the origin of the bank first arose in antiquity as the need arose for payment to be made through intermediaries. According to the second view, banks originated in the form of bank houses in Italian cities of the XIV-XV centuries, such as Venice and Genoa. Unlike the money-landers, in this case the industrial and capitalists were credited with the so-called "moderate price" [1].

As for Georgia, the first credit organization in Georgia was founded in Tbilisi in 1810 and was called "Prikaz", and the employees of this organization are "Prikazchiks". Loans were issued here, similar to today's mortgages, they received $6 \%$ per annum for the mortgage loan, and the loan amount did not exceed $50 \%$ of the pledged property. From the 1950 s onwards, the further development of the country required a more flexible credit organization, so from 1849 transformations took place and Georgia "Prikaz" was renamed "Prikaz" of the Transcaucasus and functions such as deposits and savings banks were added, where consumers received 4\% interest.

As for the beginnings of the Georgian Bank, we meet it in 1875, when the Georgian public figure of that time, Ilia Chavchavadze, established a local bank. Here the lands were pledged by the princes and they were given a certain amount of money, the peasants could buy the land with a bank loan, which maintained the agricultural sector and prevented the migration of the peasants [8].

The current Georgian banking system originated in 1991, because there were no Georgian banks during the Soviet era, the banking system in general was not allowed. There were only state-owned banks whose main function was to save money.
The establishment and development of commercial banks in Georgia began chaotically in 1991, when obtaining a banking license was not a problem for anyone. As a result, hundreds of banks were opened in two years, but for a long time none of them functioned. In many cases, banks engaged in the following activities: They took money from the population, then stopped operating and the bank owners fled the country. As a result, the already unaware population in the banking system has lost even more trust in banks. Added to this was the fact that money deposited in savings banks during the Soviet era was not returned to the people. Despite such an unfavorable background, several Georgian banks withstood the catastrophic criminal background of the 90s, and today operate in the market as trusted and large banks. According to the National Bank, the maximum number of banks in the Georgian market in 1995 was 102, and reached a minimum in 2006 with 17 banks [9].

Today, as a result of the merger of several banks, 15 banks continue to operate in the market [10].

In order for the banking process to run properly, it is necessary to regulate it through appropriate principles. The main purpose of banking regulation is to determine the potential of the country's banking system and promote its full use. Banking regulation should be systemic, regular in order to timely assess the financial condition of commercial banks, identify the circumstances that endanger the interests of the bank's customers, and check the compliance with the banking and foreign exchange legislation in the country [2].

Analysis recent research and publications. Competition between banks is the biggest challenge in the Georgian banking market. Banking competition is a process of competition between commercial banks, which in itself means achieving maximum profit sources and growth opportunities in a defined market with limited resources. Creating a competitive, flexible and reliable banking system is one of the most difficult and important problems facing the country, as the development of the country's economy significantly depends on the state and stability of the banking system [2]. 
In order to establish a perfect market economy in the country, it is necessary to promote competition, development and protection. In order for competition to serve the public interest, it must be conducted in good faith, as the consequences of uncivilized competition may have far more negative consequences for society than is expected in times of absolute monopoly. Accordingly, one of the primary tasks of the developed countries of the world is to develop legal regulation mechanisms that provide roles to identify and prevent abusive economic agents in the relevant commodity markets, as well as to promote and uphold the principles of fair competition [6].

In Georgia, the rule of supervision and regulation of banking activities serves to protect these principles and put them into practice, whose authority is granted by the National Bank under the legislation of Georgia. The National Bank has several aspects of supervision over the bank's activities, the most important of which are: capital adequacy, liquidity, asset quality, risk concentration.

Determining capital adequacy is the main lever of banking supervision and ensures the stable and sustainable functioning of the Georgian banking system by regulating bankruptcy risk minimization.Its purpose is to help reduce the risk of bankruptcy for commercial banks and the stable functioning of the entire banking system. Its fulfillment is obligatory for all commercial banks operating in Georgia and branches of foreign banks. Bank equity is the main source of financing, development, reliability and financing of the bank's business and financial losses, through which the losses are amortized, which are not covered by the depositors, but by the bank's shareholders.

For commercial banks, liquidity is the ability to meet obligations on time, especially when it comes to repaying loans obtained in the interbank market and deposits of bank customers. It is vital to maintain the bank's future existence and good reputation. With this in mind, banks need to actively manage liquidity even because their core intermediary function inevitably involves transforming loan maturities as borrowers seek to borrow over longer maturities than banks' deposit maturities.
The financial statements of a commercial bank shall contain accurate, complete and up-todate information on the financial condition of the bank, including the quality of the assets. One of the key issues for this, is whether his borrower will be able to service and repay the loan. Problems with asset quality are often the main reason for banks to go bankrupt - when the losses are too great and it is impossible to repay them at the expense of the bank's capital. The study of specific loans is central to the on-site inspection process, as early detection of problem loans is crucial. Auditors should ensure that commercial banks have developed and documented their own lending policies, principles and procedures in accordance with which they carry out lending.

Concentration of risks associated with specific counterparties is the most important component of banking supervision because the greater the concentration, the greater the potential for loss.It is a traditional decision in the field of supervision to limit the volume of operations to the level of a certain share of certain funds (capital base) with individual counter-agents or groups of counter-agents. In order to ensure the stable financial condition of commercial banks and branches of foreign banks operating in Georgia and to manage their credit risk, the National Bank of Georgia has imposed large-scale loans or other credit services by banks on one or more persons or related parties.

The total amount of loans and other liabilities issued by a commercial bank to one person should not exceed $15 \%$ of the bank's supervisory capital, and the total amount of all large loans and liabilities should not exceed $25 \%$ of the bank's supervisory capital[17].

To determine the current situation in the Georgian banking market, using the HerfindahlHirschman Index(HHI) using the net loan and total asset method below:

$$
H H I=D_{1}^{2}+D_{2}^{2}+D_{3}^{2}+\ldots . . D^{2}{ }_{n}
$$

Where $\mathrm{n}$ is the list of service providers in the market, $D_{j}$ is the share of the supplier in the market, which is calculated as follows: $D_{j}=V_{j}$ / $\mathrm{V}_{\mathrm{m}}$, where $\mathrm{V}_{\mathrm{j}}$ is the sales volume of the service provider, and $\mathrm{V}_{\mathrm{m}}$ is the total market volume. 
Table 1. Annual Report of the National Bank

\begin{tabular}{|c|c|c|c|}
\hline $\mathrm{N}$ & Bank & Total asset (Gel) & Net loan (Gel) \\
\hline 1 & JSC “TBC Bank" & $20,965,767,096$ & $13,335,876,951$ \\
\hline 2 & JSC "Bank of Georgia" & $19,342,099,382$ & $11,889,636,940$ \\
\hline 3 & JSC "Liberty Bank" & $2,763,974,341$ & $1,384,112,901$ \\
\hline 4 & JSC "VTB Bank Georgia" & $1,948,708,132$ & $1,236,167,902$ \\
\hline 5 & JSC "ProCredit Bank" & $1,743,894,693$ & $1,234,617,479$ \\
\hline 6 & JSC "Basisbank" & $1,738,232,204$ & $974,831,043$ \\
\hline 7 & JSC "Cartu Bank" & $1,407,278,603$ & $855,274,202$ \\
\hline 8 & JSC "Credo Bank" & $1,306,951,768$ & $989,717,237$ \\
\hline 9 & JSC "Terrabank" & $1,114,194,230$ & $837,882,967$ \\
\hline 10 & JSC "Khalik Bank Georgia" & $604,207,215$ & $438,352,998$ \\
\hline 11 & JSC "Pasha Bank Georgia" & $464,713,298$ & $297,479,797$ \\
\hline 12 & JSC "Ish Bank Georgia" & $324,969,632$ & $193,272,846$ \\
\hline 13 & JSC "Finca Bank Georgia" & $280,460,899$ & $176,732,993$ \\
\hline 14 & JSC "Ziraat Bank Georgia" & $123,860,995$ & $47,530,457$ \\
\hline 15 & JSC "Silk Road Bank" & $89,217,779$ & $11,820,176$ \\
\hline Source: $:$ https://www.nbg.gov.ge/index.php?m=672]
\end{tabular}

In total, third quarter of 2020 according to the latest data on the banking market, the total assets of banks amounted to GEL $54,218,530,267$, while net loans amounted to GEL 33,903,306,889.

- The market is less concentrated if the value of the HHI index does not exceed 1250;

- The market is moderately concentrated if the value of the HHI index is in the range of 1250 to 2250
- The market is highly concentrated if the value of the HHI index exceeds 2250.

According to the research, the total bank assets method is HHI $=2895$ and the total loans method is $\mathrm{HHI}=2830$.

The market evaluated by these two indicators is highly concentrated and has achieved a highly monopolized position, which prevents the establishment and maintenance of a reliable and efficient banking system (Fig. 1).

\section{Total Asset}

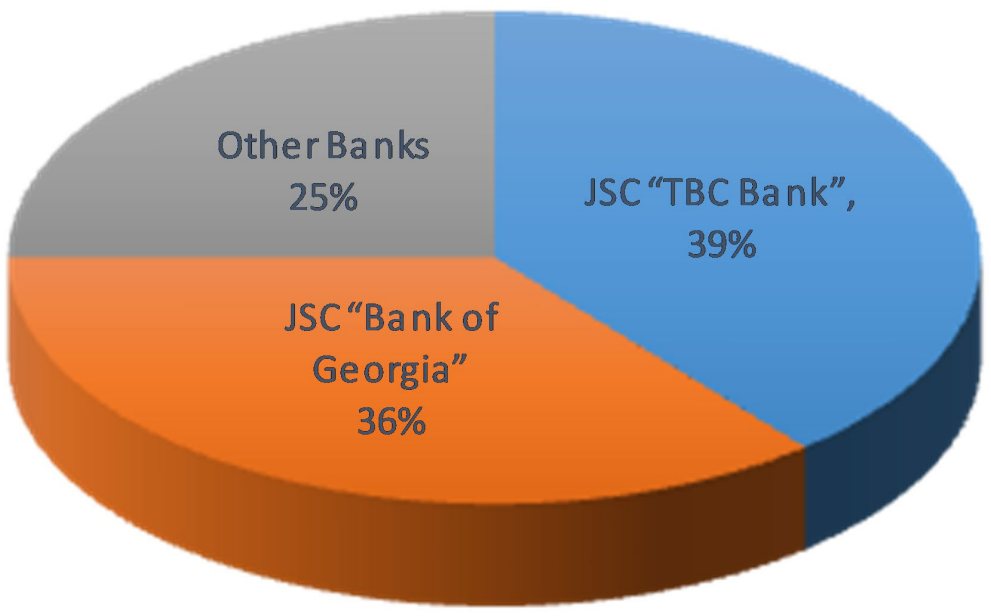

JSC "TBC Bank", - JSC "Bank of Georgia" - Other Banks

Fig. 1. Information about total asset on the Georgian banking sector

Source: Constructed and supplemented by the autor on the basis of [11] 


\section{Net Loans}

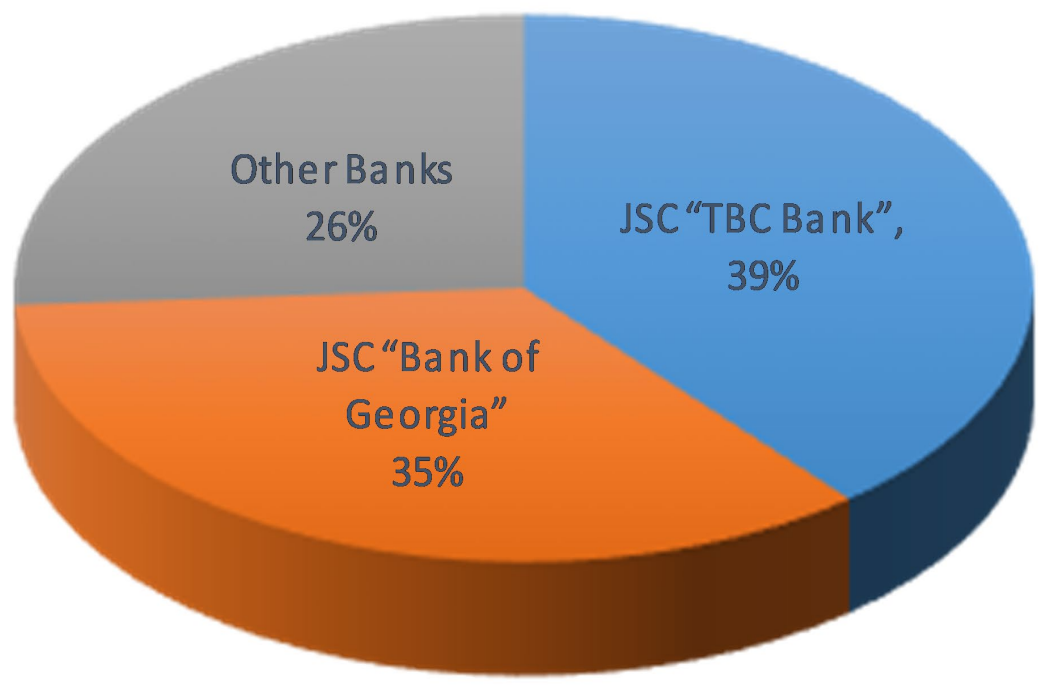

JSC "TBC Bank", घ JSC "Ba nk of Georgia" - Other Banks

\section{Fig. 2. Information about net loans on the Georgian banking sector}

Source: Constructed and supplemented by the autor on the basis of [11]

Total asset method below half of the market holds two banks, in total $75 \%$, and the remaining $25 \%$ is shared by 13 banks. The situation is similar with net loans (Fig. 2).

When a market is saturated with perfect competition, none of the market participants has the power to influence the market price and is forced to accept the price set by the market. On the other side of the spectrum, there is a situation where there is only one or two suppliers in the market and the monopolist in the monopoly market has absolute market power to determine the price of goods or services [3]. The development and appearance of many banks in the market has created a competitive market that, as everywhere, favors customers. They can already boldly select the product or service they need on the best terms, as competition and limited consumer market resources enable them to do so.

Although there are 15 banks operating in the Georgian banking market, the market is still monopolistic, and if we add to the fact that banking products and interest rates are similar, the question arises as to what causes a large number of customers to segment towards two specific banks. The answer to this question leads to customer loyalty, which usually means their loyalty to one particular bank, which is due to various factors. The main factors, in addition to the interest rate, which does not differ much from bank to bank, include factors such as: the level of remote banking services, the number of bank branches and ATMs, cashback, etc.

Remote banking has long been established in Georgia, especially during the pandemic, when consumers avoided visiting the bank as much as possible. The pandemic period has become an even bigger challenge for the Georgian banking sector, where most of the market players occupy a small volume of the market. However, not surprisingly, the Georgian financial system proved to be one of the most resilient in terms of fighting the pandemic.

Aim and tasks. Banks have responded to new challenges as quickly as possible, strengthened and simplified digital services for their clients, and shifted the main stream of employees to remote work. Remote service was also encouraged: in addition to ATMs, customers were also given the opportunity to withdraw money at the POS terminal of pharmacies or shops, and the possibility of remote identification of the customer through the call center was simplified as much as possible, despite the fact that no bank was disrupted during the virus shock. 
It was damaged, the main reason for which was the provision of possible losses on loans, which amounted to a total of 1.22 billion GEL. As for direct lending, the demand for mortgage lending has almost halved since March, as a pandemic has given borrowers other priorities, with GEL lending up $0.8 \%$ to GEL 14.71 in March, when the sector received its first shock. Foreign currency loans totaled $\$ 1.4 \%$ and $\$$ 6.32 billion, respectively. In terms of attracted funds, deposits in GEL decreased by $7.9 \%$ in March, while in foreign currency decreased by $2.9 \%$. Due to the fact that banks were expecting a shortage of GEL resources due to the pandemic, interest rates on loans in the market increased and lending conditions became more complicated. If before the pandemic the average interest rate on consumer loans at the maximum maturity was $15 \%$, today it exceeds $18 \%$.

Results. Nevertheess, the National Bank of Georgia is actively tying to keep up with the challenges, and in order to mitigate the negative impact caused by the pandemic and to stimulate the country's economy, the NBG has developed an interim supervision plan, commercial banks eased capital requirements, resulting in a GEL 1.6 billion release for the banking sector, which banks can use to offset potential losses as well as boost lending to the economy.

Under the plan, the capital conservation buffer and part of the Pilar 2 buffer were scrapped, freeing up $\$ 1.6$ billion in capital to the banking sector to offset potential losses or increase lending to the economy. Relief of capital requirements by the National Bank should not have been used by banks to make dividends, redemptions of shares, equity investments, increase in management bonuses or other payments that would have reduced the bank's capital [12].

In the wake of COVID-19 shock, significant changes have taken place in the banking sector, easing requirements to ease bureaucratic burdens and increase operational efficiency, which has resulted in less interference in lending micromanagement when the lender can enter through the lender.There have also been a number of changes: the maximum term for mortgages has been increased to 20 years, instead of 15-year GEL loans, or loans where the borrower's income and loan currency are the same.
The amount of PTI (Loan Service Ratio) limits instead of 4 was reduced to 2, set at 30\% up to $1000 \mathrm{GEL}$ and up to $50 \%$ above 1000 GEL $[13 ; 17]$.

However, the biggest challenge was that the borrowers who lost their income could not repay the monthly loan installment, which in turn would lead to the deterioration of the credit history of the population, the accrual of fines, and so on. Under an action plan developed by the government, commercial banks have imposed a 3-month grace period on loans for borrowers to avoid payment problems and related penalties.

Loans could be deferred by any individual, and this offer has benefited more than half a million borrowers. The grace period covered both consumer and mortgage loans, card loans such as credit card and overdraft, pawn loans, fast and auto loans [15]. The amount that was not repaid during the grace period was redistributed by the bank to the remaining term of the loan, which resulted in an increase in the term of the loan, while the monthly deposit remained almost unchanged. After the expiration of the 3-month period, the possibility of deferment for the mentioned period was activated again and in total, the customers were able to use the 6-month period. The only condition for deferred loans was that customers who used several loan products had no choice but to defer one of the specific loans. The deferral applied to all loans, or in case of refusal - to none [16;18-23].

Conclusions. Finally, it must be said that the banking sector met the challenges of Covid-19 prepared. Despite the complete shock caused by the pandemic, the functioning of banking institutions was not delayed, the outflow of deposits was minimal, lending was not stopped, and the supervisory plan developed by the NBG allows us to deal with problems and the banking sector to continue to function smoothly. By reducing the capital and liquidity requirements for commercial banks by the National Bank, the sector has been able to offset potential losses and pursue real business operations, allowing for lending to the real economy. 
As for the high level of market concentration, based on the research using the method of net loans and total bank assets, we can conclude that the Georgian banking market is highly concentrated, and when competition is low and the country's central bank is not actively working to correct the process, the consumer ultimately suffers and fails to get the desired result.The level of concentration is so high that the IMF notes in IMF research and recommendations that it is necessary for at least three leading banks to place high demands on capital. This norm, known as the "Obama Bank Tax", is designed to ensure that dominant banks do not overuse their position, reduce high-risk lending, and allow other banks to thrive in healthy competition. It is this norm that will help to improve competition in the banking sector.
As for the banking supervision system, in my opinion, banking regulation should be very systematic, regular in order to timely assess the financial condition of commercial banks, identify circumstances that threaten the interests of bank customers, and check the banking and foreign exchange legislation in the country.

The NBG has recently taken a number of useful steps in terms of banking supervision, although practice shows that these steps are insufficient and need to be changed. The legislative-normative framework should be refined, a systematic analysis should be carried out to identify the strengths and weaknesses of competing banks, in order to detect problems at an early stage and eliminate shortcomings, find perfect ways of competition and determine its direction.

\section{REFERENCES}

1. Kovzinadze, I., \& Kontridze, G. (2014). Modern Banking. Tbilisi: "Dani” Publishing House.

2. Mosiashvili, V., Lomidze, F., \& Koksadze, F. (2009)."Banking. Tbilisi: "Dani” Publishing House, 10-11.

3. Japaridze, L., \& Zukakishvili, K. (2019). "Georgian Competition Law". Tbilisi.

4. Asatiani V., \& Tsaava G. (2014). "Financial Analysis of Commercial Bank Activities". Tbilisi: "Dani" Publishing House, 16-25.

5. Mosiashvili, V., Chelidze, M., \& Khidirbegishvili, N. (2017) Financial Institutions and Markets. Tbilisi: "Dani” Publishing House.

6. Petelava, S. (2007) Competition Theory and Anti-Monopoly Regulation in Georgia. Tbilisi: "Loi" Publishing House.

7. Tsaava, G., \& Khantadze, G. (2014). Banking. Tbilisi: "Dani" Publishing House.

8. Kistauri, Sh. (1998). "Great Georgian banker and financier". Tbilisi: "Samtavisi" Publishing House.

9. Development of Georgian bank system (2020) Retrieved from https://forbes.ge/news/ 1674/rogor-viTardeba-qarTuli-sabanko-sistema

10. National Bank of Georgia (2021) Bank organizations licensed in Georgia Retrieved from https://www.nbg.gov.ge/ index.php? $\mathrm{m}=403$

11. National Bank of Georgia (2021) Annual Report of the National Bank Retrieved from https://www.nbg.gov.ge/ index.php? $\mathrm{m}=672$

12. National Bank of Georgia ( 2021) An interim supervision plan of the National Bank Of Georgia Retrieved from https://www.nbg.gov.ge/index.php?m=340\&newsid=3901

13. National Bank of Georgia (2021) The amount of PTI (Loan Service Ratio) in Georgia Retrieved from https://www.nbg.gov.ge/index.php?m=340\&newsid=3881

14. National Bank of Georgia (2021) Basic Principles of Banking Supervision Retrieved from https://www.nbg.gov.ge/ index.php?m=354 
15. TBC Bank (2020). 3-month suspension period on loans. Retrieved from https://www.tbcbank.ge/web/ka/3-month-suspension-period

16. Bank of Georgia (2020). Retrieved from https://bankofgeorgia.ge

17. Legislative Herald of Georgia (2013) Obtained by the Order of the President of the National Bank of Georgia N 100/04 28/10/2013 on the approval of the Regulation on the capital adequacy requirements of commercial banks Retrieved from https://matsne.gov.ge $/ \mathrm{ka} /$ document/view/2060636? publication $=0$

18. Tamosiuniene, R., Demianchuk, M., Koval, V. (2019). State Regulation of Bankruptcy Relations in the National Economy. Economics. Ecology. Socium, 3 (4), 19-27

19. Chauvet, L., \& Jacolin, L. (2017). Financial inclusion, bank concentration, and firm performance. World Development, 97, 1-13

20. Nazarova, K., Hordopolov, V., Kopotiienko, T., Miniailo, V., Koval, V., \& Diachenko, Y. (2019). Audit in the state economic security system. Management Theory and Studies for Rural Business and Infrastructure Development, 41(3), 419-430

21. Beck, T., Demirgüç-Kunt, A., \& Levine, R. (2006). Bank concentration, competition, and crises: First results. Journal of banking \& finance, 30(5), 1581-1603.

22. Vallascas, F., Mollah, S., \& Keasey, K. (2017). Does the impact of board independence on large bank risks change after the global financial crisis?. Journal of Corporate Finance, 44, 149166

23. Cull, R., Peria, M. S. M., \& Verrier, J. (2018). Bank ownership: Trends and implications. The World Bank. 